\title{
From Housing Wealth to Mortgage Debt: The Emergence of Britain's Asset-Shaped Welfare State
}

\author{
Stuart G. Lowe*, Beverley A. Searle** and Susan J. Smith*** \\ * Department of Social Policy and Social Work, University of York \\ E-mail: stuart.lowe@york.ac.uk \\ **Centre for Housing Research, University of St Andrews \\ E-mail: bas4@st-andrews.ac.uk \\ *** Department of Geography, University of Cambridge \\ E-mail: mistress@girton.cam.ac.uk
}

Housing has been unjustifiably neglected in comparative welfare state research. The banking crisis of 2007-08, however, revealed how important housing, especially home ownership and the institutional structures of the mortgage market, has become to welfare state change. Securitisation of mortgages created a new circuit of global capital, while national mortgage markets became the conduit through which home owners were connected to this wave of globally sourced capital. In the UK, equity stored in owner-occupied property became much more fungible because of the very open/liberal mortgage market. As a result home owners began to 'bank' on their homes using it not only for consumption but increasingly as a financial safety net, a cushion against adversity and a means for securing access to privately supplied services and supporting their family's welfare needs across the life-course. This welfare state change - a move towards assetbased welfare - was historically and today remains underpinned by the emergence of the $U K$ as a home-owning society.

Keywords: Housing, social policy, asset-based welfare, equity withdrawal.

\section{Introduction: housing and social policy}

This article offers an assessment of the theoretical and practical relevance of the role of asset-based welfare, particularly its significance in the formation of post-industrial welfare states. For three decades, before the banking crisis of 2007-08, literally thousands of mortgage products enabled home owners to rethink their welfare strategies. Since the 1980s, in situ re-mortgaging has been the conduit that connected huge new flows of global capital - much of it derived from Mortgage Backed Securities (MBS) in the US housing market - to individual home owners, changing attitudes to how these households thought about their home and opening up new opportunities to access welfare and care needs. British home owners came literally to 'bank' on housing (Smith and Searle, 2008), thinking of it not just as a means to advance consumption but principally as a resource to fall back on. Evidence suggests that this behaviour goes well beyond planning for older age, a 'really big trade-off' between low housing costs and pensions (Castles, 2005; Kemeny, 2005) to something much more substantial, a 'really, really big trade-off' at all stages across the life-course. What this means is that there needs to be a reassessment of the relationship between housing and welfare state change. 
The principal focus of the article is on the UK, but we argue that it is impossible to understand what is happening here as a stand-alone case. Key to the significance of asset-based welfare has been the globalisation of mortgage markets since the liberalisation of the banking system in the 1980s, and this is discussed in the first section. The next section outlines the debate about the trade-off between pensions planning and incentives toward home ownership conducted between Kemeny and Castles. The following section discusses early writing about asset-based welfare which began to appear in the UK literature in the 1980s. Finally, we review evidence about the stepping up of the practice of equity withdrawal following the globalisation of mortgage markets which created attitudes unthinkable only a few years ago but which are at the heart of asset-based welfare.

We begin by sketching a conceptual landscape against which this material needs to be read because it is difficult to make sense of the idea of asset-based welfare without reference to the wider comparative welfare state literature. To paraphrase Skocpol, housing needs to be brought back in before it can be appreciated just how important it has become to welfare state scholarship and the realities of how people manage their welfare and care needs in the circumstances of a twenty-first century home-owning society (Skocpol, 1985).

\section{Housing and the welfare state}

A major problem in comparative welfare state research was that 'housing' was missing from most of the key literature. This makes it difficult to assess the significance of recent work on asset-based welfare, which hinges to a large extent on home owners unlocking equity from their properties. So one theme of this article is to make this connection or reconnection much more explicit. The neglect of housing in the comparative welfare state literature would seem to stem from some confusion about whether housing should be thought of as a core welfare state pillar or as a commodity bought and sold in a market. It would certainly appear that housing did not fit very easily with early research on the traditional welfare state pillars or even with the more recent studies which began the 'divergence' debate about welfare state 'families of nations' and 'regimes' (Kemeny and Lowe, 1998). Wilensky, for example, in one of the earliest comparative studies, dismissed housing as too complicated to include (Wilensky, 1975). In the new wave of discussion that emerged in the 1990s, housing was at best a marginal analytical variable. Heidenheimer et al., (1990), Castles (1998), Pierson (1994, 2001) and Swank (2001), for example, all down-played the role of housing in their otherwise pathbreaking accounts of welfare state change. The most famous and influential text in this scholarship, EspingAndersen's The Three Worlds of Welfare Capitalism (1990), made almost no reference to housing. In the UK's social policy research domain, 'housing studies' has been an important subject but here too, coming from the opposite direction, the connection of housing to the wider welfare state, research and scholarship has been rather limited, with a few notable exceptions (Doling, 1997; Clapham et al., 1990). Our general point is that this neglect can no longer be sustained certainly in the UK case, in the face of the completion of the 'home-owning society' project and the demise of state housing into a shrinking residual housing tenure. Indeed the Localism Act 2011 bangs the final nails in the coffin of the long tradition of council housing through the plan to end 'tenancies for life', the long-held tradition of the provision of permanent, secure accommodation for low-income households. 
'Housing' research has reached a historical juncture where its neglect and rather marginal role in thinking about welfare states needs radical and rapid overhauling. If nothing else, the recent banking crisis revealed the extent to which 'housing' in its wider sense was complicit in the events of 2007-08 because it was the massive scale of bad debts accumulated in parts of the US prime housing market (Mian and Sufi, 2009) but particularly in the sub-prime market, with serious errors made by credit-rating agencies about the value of this debt, that triggered the crisis (Immergluck, 2009). The bursting of the global financial bubble was rooted in the 'ordinary' economy, and driven by a mix of social as well as financial needs, following a period of unprecedented growth in house prices across most but not all of the OECD countries (Hennigan, 2008; Renaud and Kim, 2007; Kim and Renaud, 2009). This was underpinned by the invention of new forms of financial trading, principally the process known as 'securitisation'. This was a way of bundling up mortgages into bonds that are then sold by the banks to investors, creating a supply of new capital, whilst offloading the long-term risks to other institutions. In this process, mortgage markets stopped being basically national and became truly global institutions. New ways of funding mortgage markets and the many thousands of products that connected home owners to globally sourced capital powerfully influenced the way that owner-occupiers began to think directly about their properties as commodities or investments as well as being their homes. The context in which this happened and the sheer scale gives fresh urgency to the need to renew our thinking about the relationship between housing and welfare states.

\section{The global explosion of capital}

Our argument is that for almost three decades the planet was immersed in a financial revolution that changed peoples' lives everywhere because 'housing' was the conduit through which home owners were connected to a surge of new capital. This financial tsunami had major implications for consumption and, as will be discussed in this article, how we need to think about welfare states. Albeit that the world economy was growing rapidly, nowhere among the industrialised nations, certainly for the members of the OECD, was there immunity from impact by these new sources of global credit. The major consequence of the combination of cheap debt and access to global capital was a surge in house prices almost everywhere lasting for nearly three decades, rising sharply after 1995 and peaking between 2000-05. Between 1995 and 2005 house prices rose in Ireland by 180 per cent, in the UK by 133 per cent, Spain by 105 per cent, France 99 per cent, Sweden 93 per cent and the Netherlands 69 per cent. Only in Germany, Japan and Switzerland did prices remain stable or fall slightly. These global house price rises were unprecedented in history. It is abundantly clear that house price increases across many of the advanced industrial economies were synchronised and closely tied to the global expansion of credit (Kim and Renaud, 2009). As Girouard observed what came into play uniquely at this time was the globalisation of the financial circuit of credit (Girouard, 2010) so that what we have seen for the first time is a truly global rather than national scale housing boom and bust. Mirroring these price increases was, of course, a massive growth in mortgage debt, amounting in many countries to over 50 per cent of GDP (Renaud and Kim, 2007).

It does not, of course, follow that everywhere was equally impacted by the new circuit of global capital. Here is not the place to pursue this part of the argument, but it must 
be made clear that while the liberal economies engineered very open mortgage markets, other countries in the European context, such as France, and especially Italy, operated a much more regulated mortgage market which limited the extent to which housing assets could be accrued and stored up equity unlocked. Housing market institutions differ very considerably across the OECD nations with very different outcomes in terms of the impact on them of the global circuit of capital. We cannot pursue this line of argument here for it leads to a related debate about the extent to which Esping-Andersen's 'frozen landscape' of settled welfare state regimes began to crack or even significantly melt as a result of the global house price surge. It is clear that in some countries the impact was significant, in others relatively marginal. Our point is that this is the context against which the rest of the article sets out a preliminary examination of the UK case as it matured as a homeowning society and particularly the emergence of asset-based welfare because it is the globalisation of mortgage markets that began to unlock the full potential of asset-based welfare.

\section{The big-trade-off debate}

Until recently almost the only scholar who investigated the place of housing in welfare state theory was Jim Kemeny. His pioneering work showed the kind of processes that might work through specifically 'housing' variables to impact on welfare state development (Kemeny, 1981). Even before the recent developments, his work showed the kind of processes that were shaping outcomes. Kemeny's key observation here was that owneroccupiers come to have a specific outlook towards taxation and spending on public services, because the life-cycle patterns involved in the costs of buying a house are normally very front-loaded. Home owners have to save up for a deposit, and mortgage payments are expensive at a time when income tends to be low. This compression of costs at the beginning of a housing career eases after the mortgage is paid off, usually over 205 years. On the other hand, tenants pay their housing costs out in a much more even way, perhaps increasing during the period of child rearing but basically rent is paid over the whole of their lifetime (Kemeny, 1995). Kemeny's thesis inspired a key debate about housing and welfare state theory. Castles pointed to the trade-off between the generosity of pensions and home ownership (Castles, 1998) and later on deliberated whether housing leads or follows welfare state retrenchment. He pointed out that the trade-off might be caused not by the growth of home-owning but through weak, and weakening, welfare states, providing an incentive to owner-occupation as a means of life-cycle saving. Indeed, Kemeny conceded that what is important here is the fact of the trade-off and not its origin (Kemeny, 2005).

Other research on housing and older people followed from the Kemeny/Castles debate. Dewilde and Raemaeckers looked at rates of home-owning and the complex structure of pension markets and other retirement funding sources across a wide spectrum of countries and how people plan their long-term welfare (Dewilde and Raeymaeckers, 2008). Doling and Ronald explored the potential for home ownership to supplement pensions across a range of countries and began to draw an explicit link to the asset-based welfare debate and to the wider implications of using housing assets as a source for funding welfare (Doling and Ronald, 2010). Furthermore a report for AgeUK found that many older people were releasing equity to supplement pensions, in particular to meet essential repairs and maintenance to secure their own housing needs (Overton, 2010). In 
the UK, the implication is that as home owners build up housing-based equity it becomes a feasible policy option for governments to step back from pensions provision. This debate provided important conceptual linkage between housing and welfare state theory.

\section{Asset-based welfare}

In the UK literature, asset-based welfare emerged from a number of sources (Lowe, 1990; Hamnett, 1999) and, significantly, was not connected to the debate about home ownership and pensions. It surfaced, for example, in studies concerned with the scale of capital accumulation in housing and how this might impact on family welfare across the life-course (Lowe, 1990) and in several studies of housing inheritance (Morgan Grenfell, 1989; Hamnett et al., 1991). In this early work the emphasis was on housing equity withdrawal as lump sums at particular points in time, notably from inheritances and through trading down to a cheaper property or remortgaging during a move. Lowe and Watson (1990), for example, estimated that as far back as 1984 - and in that year alone 51,000 elderly owner-occupiers sold up, releasing $£ 1.8$ billion of equity, and using the proceeds moved into residential care (Lowe and Watson, 1990). Studies by Holmans and Frosztega (1994) and Hamnett, (1999) came to broadly similar conclusions that private sector sheltered housing and private residential care were largely sponsored through equity withdrawn from the mainstream housing market.

One of the concerns at this time was the significantly regressive tax advantage enjoyed by better-off owner-occupiers with mortgages (under the provisions of Mortgage Interest Relief - now withdrawn) that could be transferred into other areas of consumption (Westaway, 1993). Lowe extended this argument to suggest that the processes of equity leakage - by moving house (trading down), through housing inheritances and by remortgaging - might sponsor access to private services for families of all ages and, 'increasingly sponsor the wider shape and pace of welfare state restructuring' (Lowe, 1990: 59). The recovery of housing markets after the slump in the early 1990s and above all the introduction of new mortgage products that facilitated drawdown from accumulated housing wealth generated a new wave of research on the role and relevance of housing wealth for welfare (Parkinson et al., 2009; Smith et al., 2009; Smith and Searle, 2010).

The idea that housing wealth is a resource to spend from rather than accumulate for future generations was spreading. Evidence of this extraordinary attitudinal and cultural shift surfaced in a joint DWP/HMRC study which found that nearly two-thirds of home owners 'would consider' using their home to help fund retirement, and the strategy most likely to be used for this would be to trade down in the market and release equity. Nearly half the respondents believed that investing in property makes the most of their money with less than 10 per cent believing that either a personal or employer pension scheme does (6 per cent and 9 per cent respectively) (Clery et al., 2007).

What made the period after the 1990s so distinctive was the radical restructuring of the mortgage market based around the globalisation processes outlined earlier in the article. In particular, the creation of thousands of mortgage products which allowed equity borrowing in situ, that is without moving home. This has been made possible not by housing wealth per se, but as a consequence of the growing and progressive integration of housing, mortgage and financial markets (see Smith, forthcoming). Globally sourced 
capital entered domestic budgets with mortgages as the interface. Housing wealth became more fungible.

\section{The foundations of a 'housing-wealth-fare' state}

Not only had housing wealth become more accessible, but, importantly, it had become available to more households. The growth of home ownership and the accumulation of housing wealth in the UK is a well-rehearsed story. Since the 1920s there has been a steady increase in the proportion of households owning their own home and by the end of the 1990s long-term growth had stabilised at about 70 per cent of households. This latter phase coincided with the period following bank liberalisation; a relatively stable economic period with low interest rates during which house prices rose, whilst the cost of borrowing declined. Despite the slump in prices in the 1990s, by the turn of the century owner-occupied housing accounted for nearly 50 per cent of personal disposable assets. Housing was by far the largest element in personal disposable assets, far exceeding other financial holdings (stocks and shares, insurance policies etc.) and was the most widely spread across the social class spectrum.

This was a major change from the long-term story. Atkinson and his colleagues showed that in the pre-Second World War era the vast majority of wealth, measured by property, stocks and shares etc., was owned by a tiny fraction of the population (Atkinson and Harrison, 1978). But the share of wealth among the top 5 per cent of wealth holders fell from 82 per cent in 1923 to less than 60 per cent in 1960, a significant part of this change being attributed to the expansion of home ownership and house price inflation. In the early 1970s, private pensions and net housing accounted for about 30 per cent of personal sector wealth and grew to nearly 60 per cent by the late 1980s (Lowe, 1988). This figure continued to grow though the 1990s and up to 2006-08 when it reached 78 per cent, split evenly between net housing wealth and private pensions at $£ 3.5$ trillion each (ONS, 2009). The spread of home ownership down the social strata meant this new wealth was the most widely, and as shown in the ONS Wealth in Great Britain report, the most evenly distributed form of wealth. Although inequalities do exist - while the net mean value of home owners wealth in 2006-08 was $£ 205,500$, a quarter of these households had net property wealth of $£ 85,000$ or less (ONS, 2009). Nevertheless, the net effect was to redistribute wealth rather than polarise it further (Hamnett 1999; Smith, 2004), with millions of households, for the first time, possessing a housing asset base of very considerable proportions.

The above all meant that there was - again for the first time ever - the potential to secure significant 'buy-in' to the idea that housing wealth might substitute for welfare. The more people look to individual housing wealth as a source of financial security, the less they feel the need for a comprehensive welfare safety net: the more that housing safety nets cost, the less inclined people are to support collective welfare (Smith et al., 2009). Indeed, during Gordon Brown's lengthy term as Chancellor of the Exchequer, a strong signal emerged from the Treasury that the state would no longer guarantee a minimum income level but instead offer the chance to build up private assets in a culture in which a savings habit is a normal feature of everyday life (HM Treasury, 2001). As a result, definitions of citizenship began to shift so that there is no automatic right to support from the state and individuals must prove their willingness to engage in the savings culture. As 
Watson observes, welfare planning is 'encoded with covert moralizing' (Watson, 2009: 43).

The crucial point arising from this is that the increasing use of housing wealth as collateral for all kinds of borrowing is changing the role and relevance of housing wealth in relation to welfare - much as Kemeny envisaged in his earlier work (Kemeny, 1981). Thanks to the integration of housing and mortgage markets, it became increasingly possible to access and use housing generated assets across the life-course through a process of mortgage equity withdrawal - or more properly 'equity borrowing'. Equity borrowing refers to home owners' ability to increase their mortgage debt, over and above that required to pay for their housing services, whilst in situ. The obvious route is by re-mortgaging - a process encouraged as the cost of borrowing fell, home prices rose and lenders were competing for a larger slice of the de-regulated credit market. A phase of rapid product innovation introduced into standard mortgages new features that enabled borrowers to increase their debt (up to agreed limits), not only without the need to move home, but also without the need to change their mortgage product or engage in paperwork or costs of any kind (apart from servicing a larger loan). This enabled equity borrowing to enter home buyers' day-to-day decisions around spending and saving (Smith, 2008, Smith and Searle, 2008, Smith et al., 2009) - as some economists note, it is almost like using your home as an ATM (Kluyev and Mills, 2010).

These changes within the financial sector - enabling a shift in emphasis away from housing equity withdrawal (HEW) towards mortgage equity withdrawal (MEW), and from lumpy remortgaging to routine equity drawdown - are reflected in the behaviours of home owners (see Smith and Searle, 2008). HEW began to become significant in the national accounts in the early 1980 s arising from the deregulation of the money markets. Net withdrawals leapt from $£ 407$ million in 1980 to $£ 1,596$ million in 1981 and peaked prior to the slump in house prices in the 1990s at over $£ 16$ billion in 1988, a sum equivalent to over 7 per cent of consumer spending (Wilcox, 2000: 50). As new lending products and MEW vehicles became available, the amount of equity taken out of housing peaked in 2003 at nearly $£ 63$ billion, equivalent to 9 per cent of consumer spending and remained high until the banking crisis. Equity withdrawal slumped to minus $£ 24$ billion in 2009 so that overall consumer spending was significantly depressed by this switch to saving rather than borrowing (Wilcox, 2010).

\section{The 'really, really big trade-off'}

This section of the article reviews some of the evidence for the impact of equity drawdown on how home owners began to think about and use these newly available resources. For example, housing equity withdrawal of one kind or another underpins the continued growth of private residential care and nursing homes. At the other end of the age spectrum, parents secure borrowing to fund children's housing aspirations which has underpinned the critical first-time buyers market. Against a much-reduced demand (only 109,000 transactions in 2009), 80 per cent of first-time buyers relied on family money, usually by providing the mortgage deposit and often sourced by remortgaging their own houses. Without this support, the average age of first-time buyers has reached 38 (Wilcox, 2010). There is a key intergenerational dimension in this story that reaches beyond support for house purchases and is an area of research that is being pursued separately. Housing equity per se almost certainly supports an array of other privately financed welfare options. It 
has been linked, for example, to the expansion of private health provision and the growth of fee-paying private education and home tuition (recent government figures show that nearly 20 per cent of sixth form students attend independent fee paying schools); whilst research shows that older people released equity to help children and grandchildren through financially difficult periods following divorce or unemployment (Overton, 2010). This is one empirical question we ourselves are beginning to explore. Our point is that, given the scale of equity being released through housing market processes, it would not be surprising to find evidence of financial connection between households and private service provision; asset-based welfare already actively practiced over many decades.

Work by Smith and colleagues (Searle et al., 2009; Smith et al., 2010) shows the increasing significance of housing equity in planning for care needs, managing risk over the life-course and especially providing for school-aged children. This research shows that many home owners think of their home as an asset, a safety net and financial resource that can be called upon 'as a last resort' or as a means of 'survival' in times of need across the life cycle. This is the first qualitative evidence of this remarkable shift in attitude and shows that owner-occupation in Britain has become central to people's lives and expectations and is at the forefront of their financial planning (Smith et al., 2010). The same implications have been drawn from quantitative analysis in an international comparison between the UK and Australia by two of the authors here (Searle and Smith) and our collaborators at RMIT university (see Parkinson et al., 2009; Wood et al., forthcoming). Moreover, our interrogation of the British Household Panel Survey (BHPS) - a representative sample of the population - showed that nearly one third of home owners with mortgages (by far the majority) in any one year withdrew equity and that the mean amount borrowed peaked in 2007 at $£ 22,600$ (although the median amount was $£ 8,500$ ). As argued from this evidence:

It confirms that equity borrowing is not a trivial undertaking...

it also suggests that by the early 2000s equity borrowing had

become an every-day occurrence - part of the routine of mortgage

holding; a phenomenon which cannot be reduced to the irrational

exuberance of borrowers stacking up debts against a property

bubble (Smith and Searle, 2010: 344)

It was found that the common explanation of what equity borrowers use this money for had shifted away from explanations mainly connected to improving their property and building extensions (which in a sense is not really 'equity withdrawal' but a form of investment by adding value to the house) to a large but much less specified usage called 'other reasons'. It was found that people were NOT equity borrowing to buy cars and other consumables - by 2007 this explanation accounted for less than 10 per cent of the reasons for borrowing - and that nearly half the explanations fell into the catch-all category of 'other', a figure that had doubled over the 17 years of the BHPS existence. The suggestion from this was that 'the more flexible mortgages become, the more likely it is they are used to fund non-housing expenditure' (Smith and Searle, 2010: 345).

The interrogation of the BHPS data came also to a counter-intuitive result that equity released via in situ mortgage products is most frequently used not by elderly people on the classic 'life-cycle' model, but by younger people. The study found that 25-34 year olds were four times as likely to be involved with equity withdrawal and this correlates 
to the period of family formation and not impending or actual retirement (see Parkinson et al., 2009). In fact, the detailed modelling showed that the circumstances that triggered equity release were the ending of a relationship, unemployment and the presence of school-aged children in the household (see Wood et al., forthcoming). Their conclusion, which is mirrored in the Australian study, is that mortgage equity withdrawal has much less to do with consumerism ('high days and holidays') and is much more about 'the role of mortgage debt in the repositioning of housing wealth as an asset base for welfare' (Smith and Searle, 2010: 349). Equity borrowing is prompted by a series of events that are not only uninsurable through private means, but critically, no longer underpinned by state safety nets (Wood et al., forthcoming).

\section{Conclusion}

The article began by arguing that the comparative welfare state literature had a record of neglecting housing in its analytical framework, probably because of the confusion between thinking about housing as a welfare state pillar or a commodity; the classic 'wobbly pillar' syndrome (Torgersen, 1987). It has ended by suggesting that housing in fact plays a major role in welfare state decision-making both by governments but more importantly by the actions of individual home owners and their attitude towards their property. Our argument is that new flows of capital, partly generated within the US housing market, created a global mortgage market with thousands of new products that were the conduit for the connection of household budgets to a tsunami of footloose capital. The scale and penetration of this finance shook even some of the most solidly social market economies, depending on the degree of openness/liberalisation or regulation of the mortgage institutional structures.

What this round up of research shows is that the 'really, really big trade-off' is no longer between pensions and housing, but between investing in a wide range of collectively sanctioned welfare transfers. Housing wealth has the potential to legitimise a more substantial phase of welfare retrenchment than has ever been possible and at the very least that the great pillars of the welfare state - health, education and social security - are themselves underpinned by housing derived resources. The effect of this is to facilitate political decisions that might well involve reductions in welfare state spending programmes without encountering strong public opposition. For three decades, home owners of all ages, indeed especially younger property owners, were using their equity to buy into a very active asset-based welfare system. Above all, the interview evidence suggested that home owners, as they talked about it, have in mind that their home is a 'financial cushion', a 'buffer', 'something to fall back on'. It is this attitudinal shift that was at the core of the asset-based welfare state and the ability of these households to unlock the mixed economy of welfare.

Of course, the unwinding of the property boom after the banking crisis leaves a huge residue of debt for home owners, and precisely at the moment when housing assets are needed to compensate for public spending cuts prices have faltered, thousands of mortgage products have been withdrawn and in situ remortgaging drastically scaled back. But despite it all, new welfare state landscapes have been carved out because home-owning became connected to global capital flows in ways previously impossible. Asset-based welfare may for the time being be on the back foot but its institutional 
structures have been layered into society, behaviours changed and what is sure is that never again will most people think of their house as only a home.

\section{References}

Atkinson, A. B. and Harrison, A. J. (1978) Distribution of Personal Wealth in Britain, Cambridge: Cambridge University Press.

Castles, F. G. (1998) Comparative Public Policy: Patterns of Post-War Transformation, Cheltenham: Edward Elgar.

Castles, F. G. (2005) 'The Kemeny thesis revisited', Housing, Theory and Society, 22(2).

Clapham, D., Kemp, P. and Smith, S. J. (1990) Housing and Social Policy, Basingstoke: Macmillan.

Clery, E., McKay, S., Phillips, M. and Robinson, C. (2007) Attitudes to Pensions, London: DWP/HMRC.

Dewilde, C. and Raeymaeckers, P. (2008) 'The trade-off between home-ownership and pensions: individual and institutional determinants of old-age poverty', Ageing and Society, 28, 805-30.

Doling, J. (1997) Comparative Housing Policy: Government and Housing in Advanced Industrialized Countries, London: Macmillan.

Doling, J. and Ronald, R. (2010) 'Home-ownership and asset-based welfare', Journal of Housing and the Built Environment, 25, 2, 165-73.

Esping-Andersen, G. (1990) The Three Worlds of Welfare Capitalism, Cambridge: Polity Press.

Girouard, N. (2010) 'Housing and mortgage markets: an OECD perspective', in S. J. Smith and B. A. Searle (eds.), The Blackwell Companion to the Economics of Housing: The Housing Wealth of Nations, Chichester: Wiley-Blackwell.

HM Treasury (2001) Savings and Assets For All: The Modernisation of Britain's Tax and Benefits System, Number Eight, London: HMSO.

Hamnett, C. (1999) Winners and Losers - Home Ownership in Modern Britain, London: UCL Press.

Hamnett, C., Harmer, M. and Williams, P. (1991) As Safe as Houses: Housing Inheritance in Britain, London: Paul Chapman Publishing.

Heidenheimer, A. J., Heclo, H. and Adams, C. T. (1990) Comparative Public Policy: The Politics of Social Choice in America, Europe, and Japan, New York: St. Martin's Press.

Hennigan, M. (2008) International House Price Comparison 1970-2006, Findfacts, http://finfacts.comm/irishfinancereview/Irish_2/article_1012464_printer.shtm

Holmans, A. E. and Frosztega, M. (1994) House Property and Inheritance in the UK, London: HMSO.

Immergluck, D. (2009) Foreclosed, New York: Cornell University Press.

Kemeny, J. (1981) The Myth of Home Ownership: Public versus Private Choices in Housing Tenure, London: Routledge.

Kemeny, J. (1995) From Public Housing to the Social Market, London: Routledge.

Kemeny, J. (2005) "The really big trade-off" between home ownership and welfare: Castles' evaluation of the 1980 thesis, and a reformulation 25 years on', Housing and Social Theory, 22, 2, 59-75.

Kemeny, J. and Lowe, S. (1998) 'Schools of comparative housing research: from convergence to divergence', Housing Studies, 13, 2, 161-76.

Kim, K. H. and Renaud, B. (2009) 'The global house price boom and its unwinding: an analysis and a commentary', Housing Studies, 24, 1, 7-24.

Kluyev, V. and Mills, P. (2010) 'Is housing wealth an 'ATM'? International trends', in S. J. Smith and B. A. Searle (eds.), The Blackwell Companion to the Economics of Housing: The Housing Wealth of Nations, Chichester: Wiley-Blackwell.

Lowe, S. (1988) 'New patterns of wealth: the growth of owner occupation', in R. Walker and G. Parker (eds.), Money Matters: Income, Wealth and Financial Welfare, London: Sage Publications.

Lowe, S. (1990) 'Capital accumulation in home ownership and family welfare', in N. Manning and C. Ungerson (eds.), Social Policy Review 1989-90, Harlow: Longman.

\section{CAMBRIDGE JDURNALS}


Lowe, S. and Watson, S. (1990) 'From first-time buyers to last time sellers: an appraisal of equity withdrawal from the housing market between 1982 and 1988', York Department of Social Policy and Social Work, University of York.

Mian, A. and Sufi, A. (2009) 'The household leverage-driven recession of 2007-2009', University of Chicago Booth School of Business and NBER, http://ssrn.com/ abstract=1463596.

Morgan Grenfell (1989) 'Housing inheritance and wealth', Economic Review, 45, London: Morgan Grenfell.

Office of National Statistics (ONS) (2009) 'Wealth in Great Britain: main results from the wealth and assets survey, 2006/08', www.statistics.gov.uk/downloads/theme_economy/wealth-assets-20062008/Wealth_in_GB_2006_2008.pdf.

Overton, L. (2010) Housing and Finance in Later Life: A Study of Equity Release Customers, Report for AgeUK: London.

Pierson, P. (1994) Dismantling the Welfare State? Reagan, Thatcher and the Politics of Retrenchment, Cambridge: Cambridge University Press.

Pierson, P. (2001) The New Politics of the Welfare State, Oxford: Oxford University Press.

Parkinson, S., Searle, B. A., Smith, S. J., Stokes, A. and Wood, G. A. (2009) 'Mortgage equity withdrawal in Australia and Britain: towards a wealth-fare state?', European Journal of Housing Policy, 9, 4, 363-87.

Renaud, B. and Kim, K. H. (2007) 'The global housing price boom and its aftermath', Housing Finance International, 22, 2, 3-15.

Searle, B. A., Smith, S. J. and Cook, N. (2009) 'From housing wealth to well-being?', Sociology of Health and IIIness, 31, 1, 112-27.

Skocpol, T. (1985) 'Bringing the state back in: strategies of analysis in current research', in P. B. Evans., D. Reuschemeyer and T. Skocpol (eds.), Bringing the State Back In, Cambridge: Cambridge University Press.

Smith, J. (2004) 'Exploring attitudes to housing wealth and retirement', Housing Finance, 63, 34-44.

Smith, S. J. (2008) 'Owner occupation: living with a hybrid of money and materials', Environment and Planning A, 40, 520-35.

Smith, S. J. (forthcoming) "Crisis and Innovation in the Housing Economy', A Tale of Three Markets', in M. Haliossis (ed.) Financial Innovation and Economic Crisis, Cambridge, Mass: MIT Press.

Smith, S. J. (2011) 'The crisis of residential capitalism: a tale of three markets and four visions', Progress in Human Geography (in review).

Smith, S. J. and Searle, B. A. (2008) 'Dematerialising Money? Observations on the flow of wealth from housing to other things', Housing Studies, 23, 1, 21-43.

Smith, S. J. and Searle, B. A. (eds.) (2010) The Blackwell Companion to the Economics of Housing: The Housing Wealth of Nations, Chichester: Wiley-Blackwell.

Smith, S. J., Searle, B. A. and Cook, N. (2009) 'Rethinking the risks of home ownership', Journal of Social Policy, 38, 83-102.

Smith, S. J., Searle, B. A and Powells, G. (2010) 'Introduction', in S. J. Smith and B. A. Searle (eds.), The Blackwell Companion to the Economics of Housing: The Housing Wealth of Nations, Chichester: Wiley-Blackwell.

Swank, D. (2001) 'Political institutions and welfare state restructuring: the impact of institutions on social policy change in developed democracies', in P. Pierson (ed.), The New Politics of the Welfare State, Oxford: Oxford University Press.

Torgersen, U. (1987) 'Housing: the wobbly pillar under the welfare state', in B. Turner, J. Kemeny and L. Lundqvist (eds.), Between State and Market: Housing in the Post-Industrial Era, Stockholm: Almqvist and Wicksell International.

Watson, M. (2009) 'Planning for a future of asset-based welfare? New Labour, financialized economic agency and the housing market', Planning, Practice and Research, 24, 1, 41-56.

Westaway, P. (1993) Mortgage Equity Withdrawal: Causes and Consequences, National Institute of Economic and Social Research Discussion Paper 59.

\section{CAMBRIDGE JDURNALS}


Wilcox, S. (2000) Housing Finance Review 2000/2001, York: Joseph Rowntree Foundation.

Wilcox, S. (2010) Financial Barriers to Home Ownership, York, Genworth Financial/Centre for Housing Policy: University of York.

Wilensky, H. L. (1975) The Welfare State and Equality: Structural and Ideological Roots Of Public Expenditure, Berkeley, CA: University of California Press.

Wood, G., Parkinson, S., Searle, B. A. and Smith, S. J. (forthcoming) 'Motivations for equity borrowing: a welfare switching effect', submitted to Journal of Housing Economics.

\section{CAMBRIDGE JDURNALS}

